
April 1939

\title{
HEATS OF COMBUSTION OF TETRAMETHYLMETHANE AND 2-METHYLBUTANE
}

\author{
By John W. Knowlton and Frederick D. Rossini
}

\begin{abstract}
Measurements of the heats of combustion of gaseous tetramethylmethane (neopentane) and gaseous 2 -methylbutane (isopentane) in oxygen, at $25^{\circ} \mathrm{C}$ and a constant total pressure of 1 atmosphere, to form gaseous carbon dioxide and liquid water, yielded the following values in int. $\mathrm{kj} / \mathrm{mole}$ : tetramethylmethane, $3516.53 \pm 0.94 ; 2$-methylbutane, $3528.03 \pm 0.62$. Converted to kilocalories by means of the factor $1 / 4.1833$, these values become, respectively, $840.61 \pm 0.23$ and $843.36 \pm 0.15 \mathrm{kcal} / \mathrm{mole}$.

Combination of these values with those previously reported from this laboratory for normal pentane shows that, in the gaseous state at $25^{\circ} \mathrm{C}$ and 1 atmosphere, the energy content of normal pentane is greater than that of 2-methylbutane by $8.09 \pm 1.08 \mathrm{kj}$, or $1.93 \pm 0.26 \mathrm{kcal}$, per mole, and greater than that of tetramethylmethane by $19.59 \pm 1.29 \mathrm{kj}$, or $4.68 \pm 0.31 \mathrm{kcal}$, per mole.
\end{abstract}

\section{CONTENTS}

Page

I. Introduction

II. Unit of energy and molecular weights

III. Method and apparatus _.

IV. Chemical procedure

1. Preparation and purity of the materials . . . .

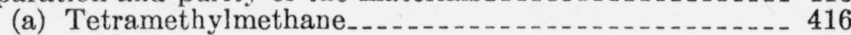

(b) 2-Methylbutane........ 417

(c) Oxygen

2. Purity of the combustion reaction

3 . Determination of the amount of reaction

V. Calorimetric procedure _...

1. Electrical-energy experiments

2. Correction experiments._._.

3. Reaction experiments ........

VI. Results of this investigation

VII. Data of previous investigations .

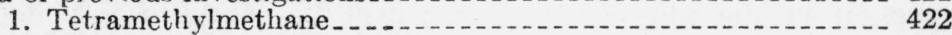

2. 2-Methylbutane

VIII. Energies of isomerization of the three pentanes.......

IX. References . . .

\section{INTRODUCTION}

Only one determination of the heat of combustion of tetramethylmethane (neopentane), that of Thomsen [1] ${ }^{1}$ in 1886 , and only one of the heat of combustion of 2-methylbutane (isopentane), that of Roth and Pahlke $[2]^{2}$ in 1936, are described in the literature. An estimate

\footnotetext{
1 Figures in brackets indicate the literature references at the end of this paper.

2 See, however, the numerical value quoted in the Landolt-Börnstein-Roth-Scheel Tabellen [3] from unpublished work of Roth and Macheleidt, which value was later withdrawn [4].
} 
of the heat of combustion of tetramethylmethane was made by one of the writers in 1935 [17]. Reliable values for these thermochemical constants are needed because of the present-day importance of the pentanes in the petroleum and synthetic chemical industries. This paper describes the calorimetric determination of the heats of combustion of tetramethylmethane and 2-methylbutane.

\section{UNIT OF ENERGY AND MOLECULAR WEIGHTS}

The unit of energy employed in this work is the NBS international joule, based upon standards of electromotive force and resistance maintained at the National Bureau of Standards. The values in terms of the fundamental unit are also converted to a conventional, defined calorie by means of the selected factor $1 / 4.1833$, which is being used by practically all thermochemical laboratories in this country [5].

The molecular weights of water and of carbon dioxide are taken as 18.0162 and $44.010 \mathrm{~g} /$ mole, respectively [6].

\section{METHOD AND APPARATUS}

The calorimetric method employed in the present investigation has been described previously $[7,8,9]$ and the reaction vessel was the same as that used in the experiments on ethylene and propylene [9].

\section{CHEMICAL PROCEDURE}

\section{PREPARATION AND PURITY OF THE MATERIALS}

(a) TETRAMETHYLMETHANE

The tetramethylmethane was prepared and purified in the chemical laboratories of the Pennsylvania State College under the direction of Frank C. Whitmore. The compound was synthesized and partially purified by Ewald Rohrmann, following the method described by Whitmore and Fleming [10]. Fraction 5, consisting of about $135 \mathrm{~g}$, or one-third of the synthetic material, had a freezing point about $1.5^{\circ} \mathrm{C}$ below that of pure tetramethylmethane. The time-temperature melting curve of this material indicated about 0.9 mole percent of impurity. The final purification of this fraction was accomplished by George H. Messerly and John G. Aston, who subjected it to fractional distillation in an all-glass, vacuum-jacketed, rectifying column packed with single-turn glass helices. The distillation was conducted at a pressure of $400 \mathrm{~mm}$ of mercury, with a reflux ratio of 5 to 1 . Middle portions of about $39 \mathrm{~g}$ and $46 \mathrm{~g}$ were collected from two separate distillations and combined to form the material sent to the National Bureau of Standards. From the results of vapor pressure measurements, and a knowledge of the estimated amount of impurity in the material before the final purification, Messerly and Aston, by comparison of similar data on different lots of tetramethylmethane previously prepared by Whitmore and his coworkers [10, 18], estimated ${ }^{3}$ the amount of impurity in the final tetramethylmethane to be about 0.3 mole percent.

To ascertain the ratio of carbon to hydrogen in the purified material, the authors performed a series of five combustion experiments, in

In a private communication to the authors. 
which the masses of carbon dioxide and water (about $4 \mathrm{~g}$ and $2 \mathrm{~g}$, respectively) were determined by a procedure previously described $[11,20,8]$. These experiments yielded, for $6 / 5$ times the ratio of the number of moles of $\mathrm{CO}_{2}$ to the number of moles of $\mathrm{H}_{2} \mathrm{O}$ formed in the combustion, the average value 0.99999 , with an uncertainty [5] of \pm 0.00014 , which ratio would be 1.00000 for pure tetramethylmethane.

From the results of these analyses, it may be concluded that the small amount of impurity in the tetramethylmethane contained carbon and hydrogen in a proportion not far from that in tetramethylmethane itself. Such an impurity would have, within the limits of accuracy of the present measurements, substantially no effect upon the heat of combustion as measured. ${ }^{4}$

\section{(b) 2.METHYLBUTANE}

The 2-methylbutane was prepared at the Bureau International des Etalons Physico-Chimiques at Brussels, and its preparation and properties have been reported by Timmermans and Martin [19]. The purity of this material was ascertained at the National Bureau of Standards by means of time-temperature cooling curves and by determination of the ratio of carbon to hydrogen.

The freezing point, determined with a platinum resistance thermometer, was found to be $-160.04 \pm 0.05^{\circ} \mathrm{C}$., which agrees well with the value $-160.0^{\circ} \mathrm{C}$ reported by Timmermans [21], who also used a platinum resistance thermometer. From the time-temperature cooling curve, the amount of liquid-soluble, solid-insoluble impurity was estimated to be less than 0.1 mole percent.

The ratio of carbon to hydrogen was determined, by the procedure previously described $[11,20,8,9]$, from 16 combustion experiments in which the masses of water and carbon dioxide collected were of the order of $2 \mathrm{~g}$ and $4 \mathrm{~g}$, respectively. The average value found for $6 / 5$ of the ratio of the number of moles of $\mathrm{CO}_{2}$ to the number of moles of $\mathrm{H}_{2} \mathrm{O}$ was 1.00005, with an uncertainty [5] of \pm 0.00016 .

\section{(c) OXYGEN}

The oxygen (prepared commercially from liquid air) used for the combustion of the hydrocarbons was purified by passage through a tube containing copper oxide at about $600^{\circ} \mathrm{C}$, and then successively through Ascarite (a mixture of sodium hydroxide and asbestos), anhydrous magnesium perchlorate, and phosphorus pentoxide.

\section{PURITY OF THE COMBUSTION REACTION}

The tetramethylmethane, previously dried by passage of the gas through anhydrous magnesium perchlorate, was burned in an atmosphere of purified oxygen in the calorimetric reaction vessel [8]. In the products of combustion of the tetramethylmethane, no carbon monoxide was found in tests which would have detected an amount corresponding to about 0.00002 mole fraction of the total carbon. ${ }^{5}$

Since 2-methylbutane is normally a liquid (boiling point $27.9^{\circ} \mathrm{C}$ at 1 atm) at the temperature at which the experiments were performed, it was necessary to carry the hydrocarbon into the calorimetric reaction vessel [8] with an inert gas-helium in this case. The procedure, in

1 See, for example, p. 40-41 of reference [20].

The tests for carbon monoxide were made by E. C. Creitz of the Gas Chemistry Section of this Bureau 
general, was the same as that previously used for normal pentane [8] and methyl and ethyl alcohols [7]. The helium was first purified by mixing with it somewhat more than the amount of oxygen required to burn all the combustible impurities, passing the gas through a tube containing copper oxide at about $600^{\circ} \mathrm{C}$, and then successively through Ascarite, anhydrous magnesium perchlorate, and phosphorus pentoxide. The helium was then passed into a saturator, where it emerged in fine bubbles from a sintered glass plate into liquid 2-methylbutane. The saturator was kept at a temperature of $18^{\circ} \mathrm{C}$, and the calculated composition of gas issuing from it was about 73 mole percent of 2methylbutane and 27 mole percent of helium. This gas was then burned in an atmosphere of oxygen in the reaction vessel. In the experiments with 2-methylbutane, the products of combustion contained carbon monoxide in an amount, on the average, corresponding to about $0.00003_{2}$ mole fraction of the total carbon. This necessitated a correction of $+0.003_{2}$ percent to the observed mass of carbon dioxide to obtain the true measure of the amount of reaction, and also a correction of $+0.001_{3}$ percent to the observed heat evolved in the calorimetric combustion experiments in order to obtain the heat which would have been evolved had no carbon monoxide been formed.

The purity of the ignition process was checked by running a series of ignitions and extinctions of the flame, in order to exaggerate greatly any abnormal effect, and then comparing the small masses of carbon dioxide and water formed. For both tetramethylmethane and 2-methylbutane, the masses of carbon dioxide and water balanced, stoichiometrically, within the limits of error of the measurements.

\section{DETERMINATION OF THE AMOUNT OF REACTION}

In the experiments on tetramethylmethane, the amount of reaction was determined $[7,8,11,20]$ from the mass of water formed in the combustion, 1 mole (18.0162 g) of water being taken as equivalent to $1 / 6$ mole of tetramethylmethane. In the experiments on 2-methylbutane, the amount of reaction was determined from the mass of carbon dioxide (corrected, where necessary, as indicated above) formed in the combustion, one mole $(44.010 \mathrm{~g})$ of carbon dioxide being taken as equivalent to $1 / 5$ mole of 2 -methylbutane. The change to carbon dioxide in the latter experiments was made because new data on the atomic weight of carbon [6] indicated that the molecular weight of carbon dioxide is now known with an uncertainty of not more than about \pm 0.003 percent, and a significantly greater precision is possible because of the greater mass (over twice that of the water) of carbon dioxide produced in the combustion. ${ }^{6}$

\section{CALORIMETRIC PROCEDURE}

\section{ELECTRICAL-ENERGY EXPERIMENTS}

The data of the electrical-energy experiments for tetramethylmethane are given in table 1 , and those for 2 -methylbutane are given in table 2. The various quantities have the same significance as in former reports (see p. 17 of reference [11] and p. 254 of reference [9]). The uncertainty, ${ }^{7}$ with regard to precision, of the average value from

6 See references [5] and [13] for further discussion of this point.

7 All the estimates of uncertainty given in this paper are made according to the procedure given in reference [5]. 
each of these two groups of experiments is $\pm 0.01_{2}$ percent. Although substantially the same calorimetric system was used for both the hydrocarbons, the values of the electrical-energy equivalent of the calorimeter, given in tables 1 and 2 , differ because, at the end of the experiments on tetramethylmethane, and before the experiments on 2-methylbutane, an accident necessitated repairs which changed the mass of glass in the reaction vessel.

TABLE 1.-Calorimetric results of the electrical-energy experiments for tetramethylmethane

\begin{tabular}{|c|c|c|c|c|c|c|c|c|}
\hline $\begin{array}{l}\text { Experiment } \\
\text { number }\end{array}$ & $\Delta R^{1}$ & $k$ & $K$ & $U$ & $\begin{array}{c}\text { Electri- } \\
\text { cal } \\
\text { energy }\end{array}$ & $\begin{array}{l}\text { Mass of } \\
\text { calor- } \\
\text { imeter } \\
\text { water }\end{array}$ & $\begin{array}{c}\text { Electrical- } \\
\text { energy } \\
\text { equivalent } \\
\text { of calorimeter } \\
\text { system 3 }^{3}\end{array}$ & $\begin{array}{l}\text { Devia- } \\
\text { tion } \\
\text { from } \\
\text { mean }\end{array}$ \\
\hline 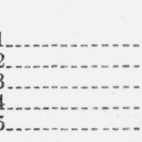 & $\begin{array}{c}\text { Ohms } \\
0.385713 \\
.396848 \\
.396303 \\
.397967 \\
.389261\end{array}$ & $\begin{array}{c}\text { Min-1 } \\
0.001940 \\
.001947 \\
.001947 \\
.001955 \\
.001934\end{array}$ & $\begin{array}{c}\text { Ohms } \\
0.007479 \\
.007109 \\
.007097 \\
.007443 \\
.007345\end{array}$ & $\begin{array}{c}\text { Ohms } \\
0.000855 \\
.000501 \\
.000768 \\
.000813 \\
.000687\end{array}$ & $\begin{array}{c}\text { Int. } j \\
56,589.9 \\
58,341.2 \\
58,241.3 \\
58,368.5 \\
57,092.2\end{array}$ & $\begin{array}{c}g \\
3530.29 \\
3528.32 \\
3529.93 \\
3524.87 \\
3525.36\end{array}$ & $\begin{array}{r}\text { Int.j/abs. ohm } \\
149,943.1 \\
149,970.7 \\
149,938.0 \\
149,986.4 \\
149,950.6\end{array}$ & $\begin{array}{r}\text { j/ohm } \\
7 . \\
35 . \\
3 . \\
50.8 \\
15 .\end{array}$ \\
\hline 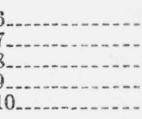 & $\begin{array}{l}.390371 \\
.391788 \\
.390643 \\
.390541 \\
.389857\end{array}$ & $\begin{array}{l}.001938 \\
.001949 \\
.001927 \\
.001924 \\
.001924\end{array}$ & $\begin{array}{l}.007233 \\
.007326 \\
.007261 \\
.007290 \\
.007221\end{array}$ & $\begin{array}{l}.000798 \\
.000831 \\
.000381 \\
.000645 \\
.000480\end{array}$ & $\begin{array}{l}57,374.5 \\
57,575.5 \\
57,494.7 \\
57,382.8 \\
57,306.3\end{array}$ & $\begin{array}{l}3533.83 \\
3533.67 \\
3534.21 \\
3531.22 \\
3530.77\end{array}$ & $\begin{array}{l}149,902.8 \\
149,928.4 \\
149,941.8 \\
149,928.2 \\
149,923.5\end{array}$ & $\begin{array}{r}-32.7 \\
-7.2 \\
6.2 \\
-7 . \\
-12.1\end{array}$ \\
\hline & .388890 & .001927 & .007301 & .000411 & $57,188.7$ & 3533.72 & $149,877.8$ & -58.1 \\
\hline \multicolumn{8}{|c|}{ - } & \pm 22.4 \\
\hline
\end{tabular}

1 The average temperature of the calorimeter was $24.94^{\circ} \mathrm{C}$, for experiment $1 ; 24.95^{\circ} \mathrm{C}$ for experiments 5 10 , and $11 ; 24.96^{\circ} \mathrm{C}$ for experiments 6,8 , and $9 ; 24.97^{\circ} \mathrm{C}$ for experiment $7 ; 24.99^{\circ} \mathrm{C}$ for experiment 3 ; and $25.00^{\circ} \mathrm{C}$ for experiments 2 and 4 .

2 The time of electrical-energy input was $1,020.00$ seconds in each experiment.

8 For $3,530.00 \mathrm{~g}$ of water and an average temperature of $25.00^{\circ} \mathrm{C}$. (See p. 416 regarding units.)

TABLE 2.-Calorimetric results of the electrical-energy experiments for 2-methylbutane

\begin{tabular}{|c|c|c|c|c|c|c|c|c|}
\hline $\begin{array}{l}\text { Experiment } \\
\text { number }\end{array}$ & $\Delta R^{1}$ & $k$ & $K$ & $U$ & $\begin{array}{c}\text { Electri- } \\
\text { cal } \\
\text { energy ? }\end{array}$ & $\begin{array}{l}\text { Mass of } \\
\text { calor- } \\
\text { imeter } \\
\text { water }\end{array}$ & 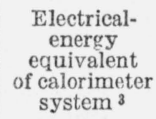 & $\begin{array}{l}\text { Devia- } \\
\text { tion } \\
\text { from } \\
\text { mean }\end{array}$ \\
\hline & $\begin{array}{l}\text { Ohms } \\
0.388380 \\
.410515 \\
.386512 \\
.385815 \\
.384867\end{array}$ & $\begin{array}{c}\text { Min-1 }^{-1} \\
0.001940 \\
.001941 \\
.001931 \\
.001958 \\
.001927\end{array}$ & $\begin{array}{c}\text { Ohms } \\
0.007485 \\
.007768 \\
.007560 \\
.007483 \\
.007515\end{array}$ & $\begin{array}{c}\text { Ohms } \\
0.000792 \\
.000543 \\
.000528 \\
.000525 \\
.000546\end{array}$ & $\begin{array}{c}\text { Int. } j \\
56,998.5 \\
60,346.1 \\
56,783.4 \\
56,632.4 \\
56,506.0\end{array}$ & $\begin{array}{c}g \\
3533.01 \\
3533.04 \\
3534.91 \\
3530.65 \\
3532.79\end{array}$ & $\begin{array}{r}\text { Int. j/abs. ohm } \\
149,830.8 \\
149,875.4 \\
149,848.9 \\
149,870.8 \\
149,844.7\end{array}$ & $\begin{array}{r}j / 0 h m \\
-22.8 \\
21.7 \\
-4.8 \\
17.1 \\
-9.0\end{array}$ \\
\hline $\begin{array}{l}6 \\
7 \ldots \\
8 \ldots . \\
9 \ldots\end{array}$ & $\begin{array}{l}.385725 \\
.384723 \\
.384655 \\
.384395\end{array}$ & $\begin{array}{l}.001934 \\
.001932 \\
.001934 \\
.001919\end{array}$ & $\begin{array}{l}.007467 \\
.007575 \\
.007572 \\
.007582\end{array}$ & $\begin{array}{l}.000594 \\
.000693 \\
.000732 \\
.000558\end{array}$ & $\begin{array}{l}56,606.4 \\
56,457.4 \\
56,459.0 \\
56,408.8\end{array}$ & $\begin{array}{l}3532.06 \\
3532.78 \\
3533.21 \\
3531.18\end{array}$ & $\begin{array}{l}149,800.4 \\
149,855.8 \\
149,883.8 \\
149,872.8\end{array}$ & $\begin{array}{r}-53.3 \\
2.1 \\
30.1 \\
19.2\end{array}$ \\
\hline \multicolumn{7}{|l|}{ Mean.... } & $149,853.7$ & \pm 19.8 \\
\hline
\end{tabular}

1 The average temperature of the calorimeter was $24.92^{\circ} \mathrm{C}$ for experiment $9 ; 24.93^{\circ} \mathrm{C}$ for experiments 5 , 6 , and $7 ; 24.94^{\circ} \mathrm{C}$ for experiments 3,4 , and $8 ; 24.95^{\circ} \mathrm{C}$ for experiment 1 ; and $25.06^{\circ} \mathrm{C}$ for experiment 2 .

The time of electrical-energy input was $1,020.00$ seconds in each experiment.

For $3,530.00 \mathrm{~g}$ of water and an average temperature of $25.00^{\circ} \mathrm{C}$. (See p. 416 reg arding units.) 


\section{CORRECTION EXPERIMENTS}

The process of ignition and extinction of the flame was checked, as in the previous investigations, by performing a series of ignitions and extinctions of the flame, and making a thermal balance of the sources and sinks of energy, namely, the "reaction," "vaporization," "gas," and "ignition" energies, each of which was evaluated as before $[11,8,9]$.

\section{REACTION EXPERIMENTS}

The data of the reaction experiments for tetramethylmethane are given in table 3 . The average value of the heat of combustion from this series of experiments has an uncertainty (with regard to precision) of \pm 0.024 percent.

The data of the reaction experiments for 2-methylbutane are given in table 4. The average value of the heat of combustion from this series of experiments has an uncertainty (with regard to precision) of \pm 0.013 percent.

TABLE 3.-Calorimetric results of the reaction experiments for tetramethylmethane

\begin{tabular}{|c|c|c|c|c|c|c|c|c|c|c|c|}
\hline $\begin{array}{c}\text { Experi- } \\
\text { ment } \\
\text { num- } \\
\text { ber }\end{array}$ & $\Delta R^{1}$ & $k$ & $\boldsymbol{K}$ & $U$ & $\begin{array}{c}\text { Electri- } \\
\text { cal-energy } \\
\text { equiva- } \\
\text { lent of } \\
\text { calorim- } \\
\text { eter } \\
\text { system }\end{array}$ & $\begin{array}{l}\text { "Gas" } \\
\text { energy }\end{array}$ & $\begin{array}{l}\text { "Igni- } \\
\text { tion" } \\
\text { energy }\end{array}$ & $\begin{array}{l}\text { "Va- } \\
\text { pori- } \\
\text { za- } \\
\text { tion" } \\
\text { energy }\end{array}$ & $\begin{array}{c}\text { Mass } \\
\text { of } \\
\text { water } \\
\text { formed } \\
\text { in the } \\
\text { reac- } \\
\text { tion }\end{array}$ & $\begin{array}{c}\text { Heat of } \\
\text { combus- } \\
\text { tion at } \\
25^{\circ} \mathrm{C} \text {. }\end{array}$ & $\begin{array}{l}\text { Devia- } \\
\text { tion } \\
\text { from } \\
\text { mean }\end{array}$ \\
\hline $\begin{array}{l}1 \\
2 \\
3 \\
4 \\
5\end{array}$ & \begin{tabular}{|l|} 
Ohms \\
0.387473 \\
.400669 \\
.401127 \\
.402122 \\
.400458
\end{tabular} & $\begin{array}{l}\text { Min-1 } \\
0.001927 \\
.001954 \\
.001933 \\
.001943 \\
.001940\end{array}$ & $\begin{array}{c}\text { Ohms } \\
0.008018 \\
.008529 \\
.007440 \\
.007688 \\
.008055\end{array}$ & $\begin{array}{c}\text { Ohms } \\
0.000408 \\
.000300 \\
.000579 \\
.000399 \\
.000354\end{array}$ & \begin{tabular}{|c|} 
Int. j/abs. \\
ohm \\
150,207 \\
150,154 \\
150,193 \\
150,101 \\
149,886
\end{tabular} & $\begin{array}{c}j \\
-3.3 \\
-5.3 \\
-4.7 \\
-11.1 \\
-1.7\end{array}$ & \begin{tabular}{l|}
$j$ \\
34.5 \\
18.4 \\
18.4 \\
29.9 \\
27.6
\end{tabular} & $\begin{array}{c}j \\
234.4 \\
259.5 \\
246.1 \\
230.2 \\
242.9\end{array}$ & $\begin{array}{c}g \\
1.75582 \\
1.81706 \\
1.82224 \\
1.82532 \\
1.81281\end{array}$ & $\begin{array}{r}\text { Int. } k j / m o l e \\
3517.76 \\
3514.86 \\
3516.23 \\
3515.13 \\
3516.94\end{array}$ & $\begin{array}{r}k j / \text { mole } \\
1.23 \\
-1.67 \\
-0.30 \\
-1.40 \\
0.41\end{array}$ \\
\hline $\begin{array}{l}6 \\
7 \\
8 \\
9 \\
10\end{array}$ & $\begin{array}{r}.401858 \\
.401585 \\
.401609 \\
.402761 \\
.402813\end{array}$ & $\begin{array}{l}.001926 \\
.001932 \\
.001933 \\
.001912 \\
.001930\end{array}$ & $\begin{array}{l}.007240 \\
.006654 \\
.006304 \\
.007979 \\
.006931\end{array}$ & $\begin{array}{l}.000435 \\
.000474 \\
.000474 \\
.000483 \\
.000594\end{array}$ & $\begin{array}{l}149,890 \\
150,197 \\
150,259 \\
149,953 \\
150,009\end{array}$ & $\begin{array}{r}-3.0 \\
-1.5 \\
-15.5 \\
-11.4 \\
-10.2\end{array}$ & $\begin{array}{l}23.0 \\
23.0 \\
23.0 \\
36.8 \\
18.4\end{array}$ & $\begin{array}{l}206.8 \\
194.4 \\
186.6 \\
243.7 \\
208.0\end{array}$ & $\begin{array}{l}1.82319 \\
1.82598 \\
1.82871 \\
1.82380 \\
1.82827\end{array}$ & $\begin{array}{l}3514.19 \\
3517.59 \\
3517.49 \\
3517.38 \\
3517.76\end{array}$ & $\begin{array}{r}-2.34 \\
1.06 \\
0.96 \\
.85 \\
1.23\end{array}$ \\
\hline & \multicolumn{9}{|c|}{ Mean... } & 3516.53 & \pm 1.15 \\
\hline
\end{tabular}

1 The average temperature of the calorimeter was $24.94^{\circ} \mathrm{C}$ for experiment $1 ; 25.01^{\circ} \mathrm{C}$ for experiments $2,3,5,6,7$, and 9 ; and $25.02^{\circ} \mathrm{C}$ for experiments 4,8 , and 10 .

2 Includes the heat capacity of one-half the mass of liquid water formed in the reaction. 
TABLE 4.-Calorimetric results of the reaction experiments for 2-methylbutane

\begin{tabular}{|c|c|c|c|c|c|c|c|c|c|c|c|}
\hline $\begin{array}{c}\text { Experi- } \\
\text { ment } \\
\text { num- } \\
\text { ber }\end{array}$ & $\Delta R^{1}$ & $k$ & $K$ & $U$ & \begin{tabular}{|} 
Electri- \\
cal-energy \\
equiva- \\
lent of \\
calorim- \\
eter \\
system 2
\end{tabular} & $\begin{array}{l}\text { "Cras", } \\
\text { energy }\end{array}$ & $\begin{array}{c}\text { "Igni- } \\
\text { tion" } \\
\text { energy }\end{array}$ & $\begin{array}{l}\text { "Va- } \\
\text { pori- } \\
\text { za- } \\
\text { tion" } \\
\text { energy }\end{array}$ & $\begin{array}{c}\text { Mass } \\
\text { of } \\
\text { carbon } \\
\text { dioxide } \\
\text { formed } \\
\text { in the } \\
\text { race. } \\
\text { tion }\end{array}$ & $\begin{array}{c}\text { Heat of } \\
\text { combus- } \\
\text { tion at } \\
25^{\circ} \mathrm{C}\end{array}$ & $\begin{array}{l}\text { Devis- } \\
\text { tion } \\
\text { from } \\
\text { mean }\end{array}$ \\
\hline & $\begin{array}{c}\text { Ohms } \\
0.399703 \\
.400214 \\
.402146 \\
.399143 \\
.399971\end{array}$ & $\begin{array}{c}\min ^{-1} \\
0.001937 \\
.001952 \\
.001969 \\
.001940 \\
.001944\end{array}$ & $\begin{array}{c}\text { Ohms } \\
0.005638 \\
.006236 \\
.005514 \\
.007268 \\
.004914\end{array}$ & $\begin{array}{c}\text { Ohms } \\
0.000260 \\
.000229 \\
.000343 \\
.000326 \\
.000350\end{array}$ & \begin{tabular}{|c|} 
Int. j/abs. \\
ohm \\
150,021 \\
150,040 \\
150,123 \\
149,984 \\
149,996
\end{tabular} & \begin{tabular}{|r|}
\multicolumn{1}{c|}{$j$} \\
2.5 \\
-1.8 \\
0.8 \\
1.0 \\
0.0
\end{tabular} & \begin{tabular}{l|}
$j$ \\
20.5 \\
41.0 \\
41.0 \\
61.5 \\
20.5
\end{tabular} & $\begin{array}{c}j \\
249.9 \\
272.7 \\
245.7 \\
322.2 \\
235.4\end{array}$ & $\begin{array}{c}\boldsymbol{g} \\
\text { 3. } 69820 \\
3.69991 \\
3.72322 \\
3.6784 \\
3.70652\end{array}$ & \begin{tabular}{|r} 
Int. $\mathrm{kj} /$ mole \\
3528.84 \\
3527.58 \\
3528.19 \\
3528.66 \\
3527.67
\end{tabular} & $\begin{array}{r}k j / \text { mole } \\
0.81 \\
-.45 \\
.16 \\
.63 \\
-.36\end{array}$ \\
\hline 10 & $\begin{array}{l}.399666 \\
.399844 \\
.400181 \\
.398234 \\
.400449\end{array}$ & $\begin{array}{l}.001923 \\
.001934 \\
.001937 \\
.001938 \\
.001924\end{array}$ & $\begin{array}{l}.006469 \\
.006187 \\
.005591 \\
.006723 \\
.005558\end{array}$ & $\begin{array}{l}.000343 \\
.000266 \\
.000299 \\
.000609 \\
.000275\end{array}$ & $\begin{array}{l}149,815 \\
149,884 \\
149,820 \\
149,856 \\
150,010\end{array}$ & $\begin{array}{r}-.9 \\
.0 \\
.9 \\
1.0 \\
-0.4\end{array}$ & $\begin{array}{l}41.0 \\
41.0 \\
20.5 \\
41.0 \\
41.0\end{array}$ & $\begin{array}{l}304.7 \\
263.7 \\
255.6 \\
304.6 \\
257.1\end{array}$ & $\begin{array}{l}3.68745 \\
3.69336 \\
3.69858 \\
3.67060 \\
3.70584\end{array}$ & $\begin{array}{l}3528.16 \\
3526.31 \\
3528.56 \\
3527.54 \\
3527.93\end{array}$ & $\begin{array}{r}.13 \\
-1.72 \\
0.53 \\
-.49 \\
-.10\end{array}$ \\
\hline 11 & .400088 & .001927 & .005261 & .000387 & 149,888 & 2.3 & 20.5 & 253.2 & 3. 70348 & 3528.91 & .88 \\
\hline \multicolumn{10}{|c|}{ Mean. } & 3528.03 & \pm 0.57 \\
\hline
\end{tabular}

1 The average temperature of the calorimeter was $25.00^{\circ} \mathrm{C}$ for experiments 6 and $9 ; 25.01^{\circ} \mathrm{C}$ for experiments $1,2,4,5,7,8,10$, and 11 ; and $25.02^{\circ} \mathrm{C}$ for experiment 3 .

2 Includes the heat capacity of one-half the mass of liquid water formed in the reaction.

3 Includes a correction of $+0.003_{3}$ percent because of the presence of a small amount of carbon monoxide in the exit gases (see p. 418).

- Includes a correction of $+0.001_{3}$ percent because of the presence of a small amount of carbon monoxide in the exit gases (see p. 418).

\section{RESULTS OF THIS INVESTIGATION}

The data of this investigation yield for the heats of combustion of tetramethylmethane and 2-methylbutane, according to the reaction

$$
\mathrm{C}_{5} \mathrm{H}_{12}(\mathrm{~g})+8 \mathrm{O}_{2}(\mathrm{~g})=5 \mathrm{CO}_{2}(\mathrm{~g})+6 \mathrm{H}_{2} \mathrm{O}(\mathrm{liq})
$$

at $25^{\circ} \mathrm{C}$ and a constant total pressure of 1 atmosphere, the values ${ }^{8}$ shown in table 5 . With these values are given the over-all uncertainties [5].

TABLE 5.-Results of the present investigation

[Reaction: $\mathrm{C}_{6} \mathrm{H}_{12}(\mathrm{~g})+8 \mathrm{O}_{2}(\mathrm{~g})=5 \mathrm{CO}_{2}(\mathrm{~g})+6 \mathrm{H}_{2} \mathrm{O}(\mathrm{liq})$ ]

\begin{tabular}{|c|c|c|c|}
\hline \multirow[t]{2}{*}{ Gas } & $\begin{array}{l}\text { Molecular } \\
\text { formula }\end{array}$ & \multicolumn{2}{|c|}{$\begin{array}{c}\text { Heat of combustion } \\
-\Delta H \text { at } 25^{\circ} \mathrm{C} \text { and } 1 \text { atmospher }\end{array}$} \\
\hline & $\mathrm{C}_{8} \mathrm{H}_{12} \ldots \ldots$ & $\begin{array}{c}\text { Int. kj/mole } 1 \\
3516.53 \pm 0.94 \\
3529.03 \pm 0.62\end{array}$ & $\begin{array}{r}\text { kcal/mole } 1 \\
840.61 \pm 0.23 . \\
843.36 \pm 0.15 .\end{array}$ \\
\hline
\end{tabular}

\footnotetext{
1 See p. 416 of text.
}

3 The value for the heat of combustion of tetramethylmethane given in tables 3 and 5 differs slightly $\left(+0.003_{3}\right.$ percent) from that reported preliminarily [12] because of the change in the accepted value for the molecular weight of water from 18.0156 to $18.0162[B]$. 


\section{DATA OF PREVIOUS INVESTIGATIONS}

\section{TETRAMETHYLMETHANE}

The literature contains only one previously reported determination of the heat of combustion of tetramethylmethane, that of Thomsen [1] in 1886. The tetramethylmethane used by Thomsen was prepared by converting trimethylcarbinol into tertiary butyl iodide and treating the latter with zinc methyl. From combustion experiments in which the masses of water and carbon dioxide were determined, Thomsen calculated the molecular formula of two different preparations of the hydrocarbon to be $\mathrm{C}_{5} \mathrm{H}_{11.78}$ and $\mathrm{C}_{5} \mathrm{H}_{11.64}$, respectively, instead of the desired $\mathrm{C}_{5} \mathrm{H}_{12}$. If the impurity was isobutene, this would indicate that the two lots contained, respectively, only about 87.6 and 79.5 mole percent of tetramethylmethane. If the impurity

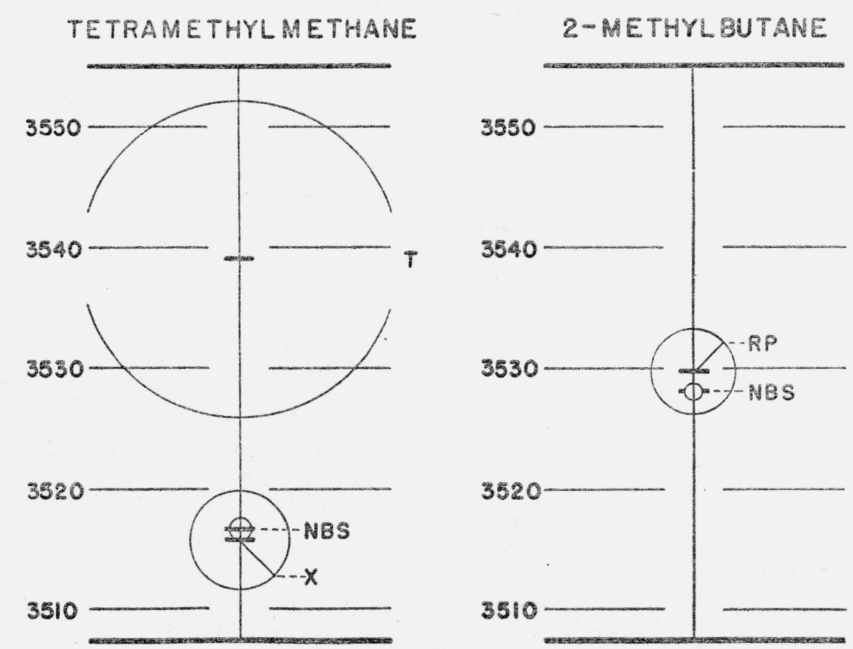

Figure 1.-Plot of the various data on the heats of combustion of tetramethylmethane and 2-methylbutane.

The scale of ordinates gives the heat of combustion, at $25^{\circ} \mathrm{C}$ and a constant total pressure of 1 atmosphere, in international kilojoules per mole. The average values, together with the estimated uncertainties (measured by the radii of the respective circles), are indicated as follows: T, Thomsen [1]; RP, Roth and Pahlke [2]; NBS, present investigation; X, value estimated for tetramethylmethane by one of the writers in 1935 [17].

was a pentene, the mole percentage of tetramethylmethane would be even less. Thomsen performed four combustion experiments in his constant-pressure flame calorimeter, using about 0.01 mole of hydrocarbon in each experiment. Making a reasonable correction for the amount of impurity, as Thomsen did, there is obtained from his data, for the heat of combustion of tetramethylmethane at $25^{\circ} \mathrm{C}$ and 1 atmosphere according to eq 1 , the value $\Delta H=-3539 \pm 13 \mathrm{int}$. kj, or $-846 \pm 3$ kcal, per mole.

In 1935 one of the writers [17] estimated, by extrapolation of the values determined in this laboratory for the heats of combustion of methane, ethane, propane, and isobutane, the value for the heat of combustion of tetramethylmethane, according to eq 1 , to be $\Delta H$ $=-3515.6 \pm 4.2$ int. $\mathrm{kj}$, or $-840.4 \pm 1.0 \mathrm{kcal}$, per mole.

The various values for tetramethylmethane are shown in figure 1. 


\section{2-METHYLBUTANE}

Only one investigation on the heat of combustion of 2-methylbutane is described in the literature, that of Roth and Pahlke [2] ${ }^{9}$ in 1936. These investigators also used 2-methylbutane from the Bureau International des Etalons Physico-Chimiques at Brussels, and burned the hydrocarbon in the gaseous phase in a bomb at constant volume, using about 0.006 mole of the hydrocarbon in each experiment. The data from the three experiments of Roth and Pahlke yield $\Delta H$ $=-3529.7 \pm 3.6$ int. $\mathrm{kj}$, or $-843.8 \pm 0.9 \mathrm{kcal}$, per mole, for the heat of combustion of 2 -methylbutane, according to eq 1 , at $25^{\circ} \mathrm{C}$ and a constant total pressure of 1 atmosphere. This value is calculated on the basis of the unit of energy, the molecular weights, and the method of estimating uncertainties used in the present report.

The various values for 2-methylbutane are shown in figure 1 .

\section{ENERGIES OF ISOMERIZATION OF THE THREE PENTANES}

Combination of the values given in table 5 with the corresponding one previously reported for gaseous normal pentane $[8,13]$ yields directly the values of the energies of isomerization of the three pentanes in the gaseous state at $25^{\circ} \mathrm{C}$ and a total pressure of 1 atmosphere. For this purpose, the value previously reported for normal pentane is corrected, for the sake of consistency, by the factor $1.00003_{3}$ to conform with the newly accepted molecular weight of water [6], the mass of which from the products of combustion was used as a measure of the amount of reaction in the experiments on normal pentane. The value for normal pentane thus becomes $3636.12 \pm 0.83$ int. kj mole. The energies of isomerization so calculated for the three pentanes are given in table 6 , and indicate that, with regard to the energy content of the molecule in the gaseous state at $25^{\circ} \mathrm{C}$, the order of decreasing stability is tetramethylmethane, 2-methylbutane, normal pentane. While the values of the entropies of all three of the pentanes are not yet accurately known, it can be estimated from the available data $[14,15,16,18]$ that, when the entropies are taken into account, the free energies of the three isomers will be in the same order of decreasing stability, although the differences will be relatively less.

The authors gratefully acknowledge their indebtedness to Frank C. Whitmore, John G. Aston, George H. Messerly, and E. Rohrman, of the Pennsylvania State College, for preparing and purifying the tetramethylmethane.

TABLE 6.-Energies of isomerization of the three pentanes

\begin{tabular}{|c|c|c|}
\hline Reaction & \multicolumn{2}{|c|}{$\begin{array}{c}\Delta H=\Delta E \text { at } 25^{\circ} \mathrm{C} \text { and a total pres- } \\
\text { sure of } 1 \text { atmosphere }\end{array}$} \\
\hline $\begin{array}{l}n \text {-Pentane }(\mathrm{g})=2 \text {-methylbutane }(\mathrm{g}) \\
n \text {-Pentane }(\mathrm{g})=\text { tetramethylmethane }(\mathrm{g}) \\
\text { 2-Methylbutane }(\mathrm{g})=\text { tetramethylmethane }(\mathrm{g})\end{array}$ & $\begin{aligned} & k j / \text { mole } \\
&-8.09 \pm 1.08 \\
&-19.59 \pm 1.29 \\
&-11.50 \pm 1.13\end{aligned}$ & $\begin{array}{l}\text { kcalimole } \\
-1.93 \pm 0.26 \\
-4.68 \pm 0.31 \\
-2.75 \pm 0.27\end{array}$ \\
\hline
\end{tabular}

See also footnote 2 on p. 415 . 


\section{REFERENCES}

[1] J. Thomsen, Thermochemische Untersuchungen, IV, (Barth, Leipzig, 1886) .

[2] W. A. Roth and H. Pahlke, Angew. Chem. 49, 618 (1936).

[3] Roth and Macheleidt, unpublished. The numerical result appears in Landolt-Börnstein-Roth-Scheel Tabellen, 5th ed., II, 1588 (Springer, Berlin, 1923).

[4] Landolt-Börnstein-Roth-Scheel Tabellen, 5th ed., second supp., p. 1634 (Springer, Berlin, 1934).

[5] F. D. Rossini, Chem. Rev. 18, 233 (1936).

[6] G. B. Baxter, O. Hönigschmid, and P. LeBeau, J. Am. Chem. Soc. 60, 737 (1938).

[7] F. D. Rossini, BS J. Research 8, 119 (1932) RP405.

[8] F. D. Rossini, BS J. Research 12, 735 (1934) RP686.

[9] F. D. Rossini and J. W. Knowlton, J. Research NBS 19, 249 (1937) RP1024.

[10] F. C. Whitmore and G. H. Fleming, J. Am. Chem. Soc. 55, 3803 (1933).

[11] F. D. Rossini, BS J. Research 6, 1 (1931) RP259.

[12] F. D. Rossini and J. W. Knowlton, J. Chem. Phys. 6, 168 (1938).

[13] F. D. Rossini, J. Research NBS 13, 21 (1934) RP692.

[14] G. S. Parks and H. M. Huffman, The Free Energies of Some Organic Compounds (Reinhold Publishing Co., New York, N. Y., 1932).

[15] L. S. Kassel, J. Chem. Phys. 4, 276, 435 (1936).

[16] K. S. Pitzer, J. Chem. Phys. 5, $473(1937)$.

[17] F. D. Rossini, J. Chem. Phys. 3, 438 (1935).

[18] J. G. Aston and G. H. Messerly, J. Am. Chem. Soc. 58, 2354 (1936).

[19] J. Timmermans and F. Martin, J. chim phys. 23, 1 (1926).

[20] F. D. Rossini, BS J. Research 6, 37 (1931) RP260.

[21] J. Timmermans, Comm. Phys. Lab. Univ. Leiden Supp. 64a, 3 (1928).

WASHINGTON, January 26, 1939. 